\title{
A Study of an Instructional Model (ASKS Model) in Physical Education to Improve Social Skills: Focusing on Team Organization*
}

\author{
Akemi Umegaki', Satoshi Otomo², Kenji Ueta², Naohiro Fukada ${ }^{3,4}$, \\ Takehito Yoshii, ${ }^{4,5}$ and Natsuki Miyao ${ }^{4,6}$ \\ ${ }^{1}$ School of Health and Sport Sciences, Osaka University of Health and Sport Sciences \\ 1-1, Asashirodai, Kumatori, Sennan, Osaka, 590-0496, Japan \\ E-mail: umegaki@ouhs.ac.jp \\ ${ }^{2}$ College of Sport and Health Science, Ritsumeikan University \\ 1-1-1, Noji-Higashi, Kusatsu, Shiga, 525-8577, Japan \\ ${ }^{3}$ Faculty of Education and Welfare, Biwako-Gakuin University \\ 29, Fusecho, Higashiohmi, Shiga, 527-8533 \\ ${ }^{4}$ Graduate School of Sport and Health Science, Ritsumeikan University \\ 1-1-1, Noji-Higashi, Kusatsu, Shiga, 525-8577, Japan \\ ${ }^{5}$ Faculty of Education, Ikuei University \\ 1-1656, Kyomemachi Takasakishi Gunma, 370-0011, Japan \\ ${ }^{6}$ Faculty of Contemporary Social Studies, Doshisha Women's College of Liberal Arts \\ Kodo, Kyotanabe, Kyoto, 610-0395, Japan
}

*Original article published in Japan J. Phys. Educ. Hlth. Sport Sci. 63: 367-381, 2018 (in Japanese).
[Received February 21, 2019; Accepted July 10, 2019; Published online July 24, 2019]

\begin{abstract}
In school education, it is important to encourage students to improve their social skills. Umegaki et al. (2016b) have developed an instructional model known as the Acquisition of Social Knowledge in Sport (ASKS) Model for facilitating improvement in social skills in the context of physical education. They consider that the ASKS Model with heterogeneous team organization would improve social skills that would be applicable to daily life outside of physical education classes and help students to maintain these social skills. However, no previous study has examined whether the ASKS Model would be effective for homogeneously organized teams. Therefore, the present study was designed to examine the type of team organization that would be most effective for the ASKS Model by comparing physical education classes with the ASKS Model based on homogeneous teams and heterogeneous teams. The study focused on physical education classes for male students in the second year of junior high school. The classes included those without the ASKS Model, those with the ASKS Model based on homogeneous teams, and those with the ASKS Model based on heterogeneous teams. A formative evaluation of friendship-building and the KiSS-18 questionnaire on paper were administered before and after each class. The study confirmed two points: First, the ASKS Model appeared to be effective when heterogeneous teams were organized. Second, the effectiveness was suggested to be improved when heterogeneity of motor skill was maintained rather than heterogeneity of social skills.
\end{abstract}

Keywords: team building, homogeneous team, heterogeneous team

\section{Introduction}

In this rapidly changing global and information society, students are required to flexibly accept various changes and to have the "skills necessary to create new value by taking the processes of trial and error and collaborating with diverse others" (Central Council for Education, 2016, p.10). The skills of collaborating with diverse others, especially, have been attracting attention as a quality and ability that would facilitate the creation of new value or the solution to complicated problems. 
For example, in 2003 the OECD suggested the key competency of the interactive use of tools (Richen and Salganik, 2003) and with the PISA 2015 survey they measured collaborative problemsolving ability*1 with which you try to solve problems while collaborating with others (Kuno, 2015, p.37). This ability contains the skills of solving complicated problems with others while sharing a purpose (Kuno, 2015, p.34). Additionally, the Assessment and Teaching of Twenty-First Century Skills Project, which was established in the US, included communication and collaboration (teamwork) in the Twenty-First Century Skills, and pointed out the necessity of qualities and abilities of creating new value and solving complicated problems while interacting with others (Griffin et al., 2014, pp.49-51).

Then, how can you foster the ability to collaborate with diverse others? One of the methods of fostering the ability to collaborate with diverse others could be to improve students' social skills. This is because social skills are the "techniques of having smooth interpersonal relations" (Kikuchi, 1988, p.189), and students who have acquired such social skills are expected to effectively deal with various situations arising from collaboration with diverse others. Social skills specifically include ones related to interpersonal relations; such as starting conversations and providing direction to others; ones to process emotions, such as expressing emotions and processing fear; ones to maintain interpersonal relations, such as handling trouble with others and making up; ones to process stress, such as processing inconsistent messages and handling accusations; and ones to get ahead with work such as deciding what to do and setting goals (Kikuchi, 1988, pp.190-193).

Additionally, in a policy dialog conducted between Japan and OECD, the necessity for newly formulating a "curriculum focusing on human character and social skills" (Curriculum Planning Special Committee, 2015, p.3) was pointed out as an opinion.

Thus, in school education, it is required to encourage students to improve their social skills.

In physical education (PE) in Japan and other developed countries, the social-behavioral area is set as one of the subject's objective areas (Tomozoe, 2010, pp.33-37). Instructional models corresponding to objectives in the social-behavioral area therefore have been developed and practiced mainly in the US. Specifically, there is the sport education model (hereinafter abbreviated as the "SE model") advocated by Siedentop (1994), cooperative learning (hereinafter abbreviated as the "CL") advocated by Dyson $(2001,2002)$, and the teaching personal and social responsibility model (hereinafter abbreviated as the "TPSR model") advocated by Hellison (2003).

The preceding studies that examined the effects of these instructional models reported that they would improve students' social skills in PE classes.

For example, Wallhead and O'Sullivan (2005) reviewed research papers that examined the effects of the SE Model and reported that the model where activities were done by homogeneous teams through a unit would facilitate the improvement of students' social skills in PE classes.

Dyson (2001) applied the CL in PE classes of the 5 th and 6th grades of elementary schools and reported that the CL encouraged students to work together as a team and improved students' social skills in PE classes such as supporting others.

Hellison and Walsh (2002) reviewed research papers that examined the effects of the TPSR model and reported that it increased students' awareness of their self-repression, self-managing and assistance to others, increased their communication skills in PE classes, and facilitated improvement of their human relations. In Japan, Umegaki et al. (2006) and Umegaki et al. (2011) reported that the TPSR model facilitated the improvement of university students' and junior high school students' social skills.

However, a challenge can be recognized in these instructional models as to the transfer of social skills that students acquired in PE classes to daily life settings outside of PE classes ${ }^{* 2}$. Gordon and Doyle (2015) sorted out studies that examined the possibility of such transfers with the TPSR model and clarified that some research results confirmed the possibility while others denied it. Additionally, Umegaki et al. (2016a) examined whether or not the TPSR model encourages the transfer of social skills that students acquired in junior high school PE classes to daily life settings and its maintenance. As a result, they clarified that the TPSR model would transfer social skills that students acquired in PE classes to daily life settings outside of PE classes but would not facilitate its maintenance. 
Based on the above, Umegaki et al. (2016b) developed a new instructional model that would transfer social skills that students acquired in PE classes to daily life settings outside of PE classes and facilitate its maintenance. The new instructional model positioned small groups organized in PE classes as a sports team and let students address team building while letting them gain knowledge necessary for it (Umegaki et al., 2016b, p.5).

Umegaki et al. (2016b) organized heterogeneous teams*3 in junior high school PE classes and conducted both intervention units that had applied the new instructional model and nonintervention units that had not applied it. The result clarified that the new instructional model would significantly increase the average scores of the social skill scale, which measured social skills in daily life settings, and would maintain the thus increased average scores of the social skill scale. That is, they clarified that the new instructional model would increase students' social skills in daily life settings and facilitate the maintenance of the thus increased social skills. Additionally, the effectiveness of the new instructional model was confirmed both in the unit for volleyball, a group sport, and in the unit for running long jump, an individual sport.

Also note that Umegaki et al. (2017) named the new instructional model the acquisition of social knowledge in sport model (hereinafter abbreviated as the "ASKS model"') because it would let students acquire knowledge necessary for team building, including knowledge related to social skills.

The ASKS model was developed as an instructional model that, by satisfying the following two conditions, would transfer social skills that students acquired in PE classes to daily life settings and facilitate the maintenance of social skills in daily life settings. The first condition was to, in light of a learning theory based on cognitivism, provide students with factual knowledge, conceptual knowledge, procedural knowledge, and meta-cognitive knowledge related to team building and to facilitate structural understanding of them (which is the setting of knowledge) (Umegaki et al., 2016b, pp.7-8). The second condition was to, in light of a learning theory based on social constructivism, facilitate interaction with others (which is the setting of interaction with others) (Umegaki et al. 2016b, p.10). Specifically, they took into consideration ability, personality and an intellectual aspect and organized heterogeneous teams to facilitate interaction with heterogeneous others.

Thus, Umegaki et al. (2016b) organized heterogeneous small groups and confirmed the effectiveness of the ASKS model in heterogeneous teams both with the unit for volleyball, a group sport, and the unit for running long jump, an individual sport. Here, heterogeneous teams were organized as a condition facilitating interaction with others. However, if you set a condition of facilitating interaction with others, the ASKS model with homogeneous team organization is also possible to conduct. Then, is the effectiveness of the ASKS model witnessed with homogeneous team organization?

Generally, it has been revealed that heterogeneous teams, in comparison with homogeneous teams, have a good influence on the performance of a group. For example, Tomita (2007) verified that the heterogeneity of members brought positive results to research and development, and Hida (2014a, 2014b) verified that the heterogeneity of members brought good results when the task was highly novel or difficult. Hida (2014c) furthermore reviewed studies that examined the impact of the heterogeneity and homogeneity of members would have on the group's performance of problem solving, and reported that the heterogeneity of members caused excellent performance. Studies focusing on learning settings also verified the superiority of heterogeneous teams to homogeneous teams (Yamashita, 2002; Kinjo, 2015).

From these, we expect that the superiority of heterogeneous teams to homogeneous teams will also be found in the ASKS model. In PE, Izuhara (1986, $1991,2004)$ has been advocating the importance of heterogeneous team organization from the viewpoint of character formation ${ }^{* 4}$ in terms of the members improving together.

In PE classes, however, there are some cases when homogeneous teams are preferred depending on sports areas. For example, in such areas as swimming and gymnastics, where the motor skill set as a target differ according to the level of students, practicing on a homogeneous team may secure the safety of the class and increase each student's motivation to facilitate the improvement of skills. Also in areas, such as ball games, where students with lower skills often cower in front of students with higher skills, practicing on homogeneous team may increase each student's motivation and facilitate the 
improvement of skills*5.

Thus in PE classes, homogeneous teams and heterogeneous teams, respectively, have their own advantages. However, to our knowledge, there seem to be no studies that compared and examined the impact of homogeneous teams or heterogeneous teams in PE classes on students' character formation based on quantitative data. Taking it into consideration that the ASKS model was developed as an instructional model that would transfer the social skills that students acquired in PE classes to daily life settings and promote maintenance in the settings, this study will examine the impacts of the ASKS model with homogeneous team organization or of the ASKS model with heterogeneous team organization on students' social skills.

The Course of Study announced in March 2017 indicated as qualities and abilities that should be fostered for students the following: (1) knowledge and skills; (2) thinking abilities, judgement, and expressive abilities; and (3) appetite for learning and human qualities (MEXT, 2017, p.4). Schools are required to realize these through the entire school education and each subject (MEXT, 2017, p.4.) However, as Okade pointed out, among the qualities and abilities that should be fostered, "the only subject that has set instructional contents related to the appetite for learning and human qualities was (health and) physical education" (Okade, 2017, p.9). The ASKS model is an instructional model that can take a direct role in cultivating an appetite for learning and human qualities in the sense that it facilitates the improvement of students' social skills. In this sense, by examining the style of team organization with which the effectiveness of the ASKS model is elicited, we may be able to provide findings significant to the improvement of school education.

Based on the above, this study aimed to examine the style of team organization with which the effectiveness of the ASKS model can be witnessed by comparing PE classes with the ASKS model with homogeneous team organization and those with heterogeneous team organization.

\section{Method}

\subsection{Examinees and terms}

We targeted PE classes with 33 male students in their 2nd grade of prefecture G's public junior high school instructed by a male teacher in his forties with 18 years of teaching experience.

Table 1 shows the schedule of class implementation, units, number of hours, with or without intervention, and implementation period of the survey. In order to collect baseline data, we conducted a unit without the ASKS model (hereinafter abbreviated as the "nonintervention unit") from May 14 to May 28, 2013. Following this, we conducted a unit with the ASKS model with homogeneous team organization (hereinafter abbreviated as the "homogeneous intervention unit") from June 4 to June 24, 2013. And, we conducted a unit with the ASKS model with heterogeneous team organization (hereinafter abbreviated as the "heterogeneous intervention unit") from March 3 to March 18, 2014.

Table 1 Schedule of class implementation, units, number of hours, with or without intervention, and implementation period of the survey.

\begin{tabular}{|c|c|c|c|c|c|c|c|c|}
\hline & \multicolumn{8}{|c|}{ period } \\
\hline & $\begin{array}{l}5 / 14 \\
2013\end{array}$ & $\begin{array}{c}5 / 14-5 / 28 \\
2013\end{array}$ & $\begin{array}{l}5 / 28 \\
2013\end{array}$ & $\begin{array}{c}6 / 4-6 / 24 \\
2013\end{array}$ & $\begin{array}{l}6 / 24 \\
2013\end{array}$ & $\begin{array}{c}3 / 3 \\
2014\end{array}$ & $\begin{array}{c}3 / 3-3 / 18 \\
2014\end{array}$ & $\begin{array}{l}3 / 18 \\
2014\end{array}$ \\
\hline Unit & & $\begin{array}{l}\text { Short-distance } \\
\text { race and relay }\end{array}$ & & $\begin{array}{l}\text { Exercise using } \\
\text { vaulting boxes }\end{array}$ & & & Basketball & \\
\hline $\begin{array}{c}\text { Number of } \\
\text { hours }\end{array}$ & & 6 & & 8 & & & 8 & \\
\hline Intervention & & $\begin{array}{c}\text { Non- } \\
\text { intervention }\end{array}$ & & $\begin{array}{c}\text { ASKS model } \\
\text { (homogeneous } \\
\text { team) }\end{array}$ & & & $\begin{array}{c}\text { ASKS model } \\
\text { (heterogeneous } \\
\text { team) }\end{array}$ & \\
\hline $\begin{array}{l}\text { Period of } \\
\text { surver }\end{array}$ & $\begin{array}{c}\text { Survey } \\
\text { implementation }\end{array}$ & & $\begin{array}{c}\text { Survey } \\
\text { implementation }\end{array}$ & & $\begin{array}{c}\text { Survey } \\
\text { implementation }\end{array}$ & $\begin{array}{c}\text { Survey } \\
\text { implementation }\end{array}$ & & $\begin{array}{c}\text { Survey } \\
\text { implementation }\end{array}$ \\
\hline
\end{tabular}




\subsection{Settings and instruction methods of the ASKS model}

In this study, we set the ASKS model from the following two viewpoints; (1) setting of knowledge necessary for team building, and (2) setting of interaction with others.

As for (1) setting of knowledge necessary for team building, we set the same instructional contents both for the homogeneous intervention unit and the heterogeneous intervention unit.

Table 2 shows the instructional contents on knowledge in the ASKS model. They are the same contents as those set by Umegaki et al. (2016b). In order to transfer the social skills that students acquired in PE classes to daily life settings and facilitate their maintenance, and based on a taxonomy of educational objectives by Anderson et al. (2001) we set objectives and assessments for each class hours. Specifically, we linked Knowledge 1 to 7 shown in Table 2 with the dimensions of knowledge from "factual knowledge" to "meta-cognitive knowledge" and the dimensions of cognitive process from "remember" to "create" to set the objectives, and set the assessments in accordance with each objective. Table 3 shows the objectives related to the knowledge taught in the ASKS model, class hours, and evaluation setting.

The objectives for the first period of the unit were to remember the "characteristics of teams" and to understand "what a team is" (Knowledge 1), and the objectives for the second period were to remember the "factors of teamwork" and to understand "what teamwork is" (Knowledge 2). The assessments were done through a confirmation test conducted at the end of each class.

The objective for the third to sixth periods of the unit was to create an ideal team using the "methods to improve teamwork", which is the knowledge related to the team building measures falling on Knowledge 3 to 6 . The assessments were done through observational evaluations on the state of each team conducted by teacher during the class, and self-evaluations by students about the state of their own teams conducted at the end of each class.

The objectives for the seventh period of the unit were to analyze the state of students' own team based on the Knowledge 7, the "developmental process of a team", and to evaluate the state of their own team based on the Knowledge 7, the "de- velopmental process of a team". The assessment was done through observational evaluations on the state of each team conducted by teacher during the class, and self-evaluations by students about the state of their own team conducted at the end of the class.

The objective for the third to eighth periods of the unit was to create an ideal team using the "methods to improve teamwork" falling on Knowledge 3 to 6 . The assessments were done through presentations by students about the developmental process of their own team and the state of the team during the eighth period.

Specific instructional method was as follows:

The teacher, when conducting classes, explained Knowledge 1 to 7 using display materials on which the instructional contents in knowledge were written so that students were able to fully understand them. Table 4 shows an example of display materials.

The teacher also instructed students to address team building by using the knowledge they acquired during the classes. Specifically, he said, "It's important to put into action the methods of communication you learned today", "Do you understand your own role? It's important to fulfill your role', and so on. Additionally, he observed whether or not students were using the knowledge they learned during the classes and gave proper advice.

At the end of each classes, he conducted a confirmation test on the knowledge they learned during the classes*6. He also had students review the degree of growth of their own teams and the activities of the members on their team.

As for (2) setting of interaction with others, we organized homogenous teams in a homogenous intervention unit, and heterogeneous teams in a heterogeneous intervention unit. Specifically, it was as follows.

In the homogeneous intervention unit where students performed the exercise using vaulting boxes, the teacher classified students in three grades in accordance with their exercise using vaulting boxes skill to organize teams by grade. He organized two teams respectively for those with a high skill, those with a middle-grade skill, and those with a low skill. The number of each team was five to six.

In the heterogeneous intervention unit where students played basketball, the teacher organized four heterogeneous teams to which he assigned to each team three to four students belonging to the basket- 
Table 2 Instructional contents on knowledge in the ASKS model.

\begin{tabular}{|c|c|c|c|}
\hline & \multicolumn{2}{|c|}{ Instructional contents } & \multirow{2}{*}{ Examples of instruction } \\
\hline & Item & Specific contents & \\
\hline Knowledge 1 & What a team is & $\begin{array}{l}\text { Difference between a } \\
\text { team and a group } \\
\text { Characteristics of teams }\end{array}$ & $\begin{array}{l}\text { A team is members working together and fulfilling their duty in } \\
\text { order to achieve their goals. A team has the following four fea- } \\
\text { tures. (1) There is a goal. (2) All members work together. (3) Each } \\
\text { member shares different roles. (4) There is a sense of unity among } \\
\text { team members. }\end{array}$ \\
\hline Knowledge 2 & What teamwork is & Factors of teamwork & $\begin{array}{l}\text { (1) All members have good communication. (2) All members have } \\
\text { affection for the team. (3) Leaders understand their role and fulfill } \\
\text { their mission. (4) All members understand the state of their own } \\
\text { team and act for the team's growth. }\end{array}$ \\
\hline Knowledge 3 & $\begin{array}{l}\text { Methods to improve } \\
\text { teamwork } 1\end{array}$ & Communication & $\begin{array}{l}\text { Understanding the personality and skill level of all members, giv- } \\
\text { ing advice in accordance with each member's personality and skill } \\
\text { level (facial expression, voice tones, words of encouragement, } \\
\text { etc.), sharing the joy together when successful, and creating origi- } \\
\text { nal characteristics different from other teams. }\end{array}$ \\
\hline Knowledge 4 & $\begin{array}{l}\text { Methods to improve } \\
\text { teamwork } 2\end{array}$ & $\begin{array}{l}\text { Affection towards } \\
\text { the team }\end{array}$ & $\begin{array}{l}\text { Making an effort to improve their skills for the team, giving an } \\
\text { opinion in every discussion, asking those who do not express opin- } \\
\text { ions for their viewpoints, not forgetting their own roles and fulfil- } \\
\text { ling the responsibility properly, and creating a harmonious team } \\
\text { atmosphere. }\end{array}$ \\
\hline Knowledge 5 & $\begin{array}{l}\text { Methods to improve } \\
\text { teamwork } 3\end{array}$ & Leadership & $\begin{array}{l}\text { Informing every teammate of the team's goal and the role of each } \\
\text { member, resolving a conflict smoothly through discussion if there } \\
\text { is one, accepting all members and listening well to their opinions, } \\
\text { respecting the members' opinion, and on occasion letting them } \\
\text { take the initiative. }\end{array}$ \\
\hline Knowledge 6 & $\begin{array}{l}\text { Methods to improve } \\
\text { teamwork } 4\end{array}$ & $\begin{array}{l}\text { Understanding and } \\
\text { mutual support among } \\
\text { the team members }\end{array}$ & $\begin{array}{l}\text { Finding out who is not good at what and giving them the } \\
\text { appropriate advice, understanding which member is not grasping } \\
\text { the team's goal and strategies and teaching them, and then build- } \\
\text { ing a strategy in which everyone can play an active part. }\end{array}$ \\
\hline Knowledge 7 & $\begin{array}{l}\text { Developmental } \\
\text { process of a team }\end{array}$ & $\begin{array}{c}\text { Analysis and evaluation } \\
\text { of their own team }\end{array}$ & $\begin{array}{l}\text { The team understands which of the following types they fall into. } \\
\text { Type 0: The team is not well unified and it is not falling into any } \\
\text { of the following types. } \\
\text { Type 1: The team consists of members with low maturity. An offi- } \\
\text { cial leader takes vertical leadership of each member individually. } \\
\text { Type 2: It is in the state where cooperation is established mutually } \\
\text { between each member. Mutual influences can be seen between the } \\
\text { leader and members. } \\
\text { Type 3: Mutual cooperation among the team members is strong, } \\
\text { and teamwork is excellent. Other members than the leader start } \\
\text { taking a part in the leadership role. } \\
\text { Type 4: Maturity of members is increased, and leadership is } \\
\text { demonstrated by the members. It is in the state where every mem- } \\
\text { ber can be a leader. }\end{array}$ \\
\hline
\end{tabular}

* Quoted from Umegaki et al. (2016b, p. 7)

ball club and one to two students having leadership. The number of each of the team members was seven to nine.

Specific instruction methods were as follows for both the homogeneous intervention unit and the heterogeneous intervention unit: The teacher organized teams during the first period of the unit to let students become aware that they would build an ideal team throughout the unit. Specifically, he taught that students would study about the knowledge necessary for team building in every class; they would build a team using this knowledge, all the members would actively participate in team building, and they would need to discuss and communi- 
Table 3 Objectives related to the knowledge taught in the ASKS model, class hours, and evaluation setting.

\begin{tabular}{|c|c|c|c|c|c|c|}
\hline \multirow{2}{*}{$\begin{array}{l}\text { The } \\
\text { knowledge } \\
\text { dimension }\end{array}$} & \multicolumn{6}{|c|}{ The cognitive process dimension } \\
\hline & Remember & Understand & Apply & Analyze & Evaluate & Create \\
\hline $\begin{array}{c}\text { Factual } \\
\text { knowledge }\end{array}$ & $\begin{array}{l}\text {-Objective } 1 \\
\text { - Class hours } \\
1^{\text {st }} \text { and } 2^{\text {nd }} \text { period } \\
\text {-Assessment A }\end{array}$ & & & & & \\
\hline $\begin{array}{l}\text { Conceptual } \\
\text { knowledge }\end{array}$ & & $\begin{array}{l}\text {-Objective } 2 \\
\text {-Class hours } \\
1^{\text {st }} \text { and } 2^{\text {nd }} \text { period } \\
\text {-Assessment A }\end{array}$ & & & & \\
\hline $\begin{array}{l}\text { Procedural } \\
\text { knowledge }\end{array}$ & & & $\begin{array}{l}\text {-Objective } 3 \\
\text { - Class hours } \\
3^{\text {rd }} \text { to } 6^{\text {th }} \text { period } \\
\text { - Assessment B } \\
\text { and C }\end{array}$ & & & $\begin{array}{l}\text {-Objective } 3 \\
\text {-Class hours } \\
3^{\text {rd }} \text { to } 8^{\text {th }} \text { period } \\
\text {-Assessment D }\end{array}$ \\
\hline $\begin{array}{l}\text { Meta-cognitive } \\
\text { knowledge }\end{array}$ & & & & $\begin{array}{l}\text {-Objective } 4 \\
\text {-Class hours } \\
7^{\text {th }} \text { period } \\
\text {-Assessment B } \\
\text { and C }\end{array}$ & $\begin{array}{l}\text {-Objective } 5 \\
\text {-Class hours } \\
7^{\text {th }} \text { period } \\
\text {-Assessment B } \\
\text { and C }\end{array}$ & \\
\hline
\end{tabular}

Objective $1=$ Remember "Characteristics of teams" in Knowledge 1 and "Factors of teamwork" in Knowledge 2.

Objective $2=$ Understand "What a team is" in Knowledge 1 and "What teamwork is" in Knowledge 2.

Objective $3=$ Create an ideal team by utilizing the knowledge of "Methods to improve teamwork" in Knowledge 3 to Knowledge 6 . Objective $4=$ Analyze the state of their own team based on the knowledge of "Developmental process of a team" in Knowledge 7. Objective $5=$ Evaluate the state of their own team based on the knowledge of "Developmental process of a team" in Knowledge 7 . Assessment $\mathrm{A}=$ Confirmation test

Assessment $\mathrm{B}=$ Observational evaluations by teachers

Assessment $\mathrm{C}=$ Self-evaluation by students

Assessment $\mathrm{D}=$ Presentations by students about the developmental process of their own team

* Written by the author by referring to Anderson et al. (2001, p. 183) and Ishii (2011, p. 97)

Table 4 Description for "What a team is" in Knowledge 1.

\begin{tabular}{|c|l|}
\hline & (1) There is a goal. \\
Characteristics & (2) Members work together. \\
of a team & (3) Each member shares a different role. \\
& (4) There is a sense of unity among the \\
members.
\end{tabular}

cate with each other.

In and after the second period of the unit, the teacher observed the teams to check whether or not the students were building a team by using the knowledge they learned during the classes and gave proper advice. He also announced, to all the students, teams that used unique expressions to improve teamwork, such as doing high fives and huddling, students who fully played their own role in order to contribute to team building, and leaders who let each member of their team become aware of the team's goal.

\subsection{Unit plan of PE with the ASKS model}

Table 5 shows the unit plan for exercise using vaulting boxes with the ASKS model on homogeneous team organization, and Table 6 shows the unit plan for basketball with the ASKS model on heterogeneous team organization.

The same instructional contents of the ASKS model were set for both the homogeneous intervention unit and heterogeneous intervention unit, except that the team organization was different. Specifically, students were set to study one kind of knowledge in each class from among Knowledge 1 to 7 to gain the knowledge necessary for team building. At the end of the eighth period, students summarized their team building and reviewed the developmental process of their own team. 
Table 5 Unit plan for exercise using vaulting boxes.

\begin{tabular}{|c|c|c|c|c|c|c|c|c|}
\hline & $1^{\text {st }}$ period & $2^{\text {nd }}$ period & $3^{\text {rd }}$ period & $4^{\text {th }}$ period & $5^{\text {th }}$ period & $6^{\text {th }}$ period & $7^{\text {th }}$ period & $8^{\text {th }}$ period \\
\hline \multirow[b]{2}{*}{$5 \mathrm{~min}$} & \multicolumn{7}{|c|}{ Warm-up, greeting } & \multirow[b]{2}{*}{$\begin{array}{l}\text { Warm-up } \\
\text { Greeting } \\
\text { Confirmation } \\
\text { of tasks }\end{array}$} \\
\hline & $\begin{array}{l}\text { Knowledge } 1 \\
\text { What a } \\
\text { team is }\end{array}$ & $\begin{array}{l}\text { Knowledge } 2 \\
\text { What } \\
\text { teamwork is }\end{array}$ & $\begin{array}{l}\text { Knowledge } 3 \\
\text { Methods to } \\
\text { improve } \\
\text { teamwork } 1\end{array}$ & $\begin{array}{l}\text { Knowledge } 4 \\
\text { Methods to } \\
\text { improve } \\
\text { teamwork } 2\end{array}$ & $\begin{array}{l}\text { Knowledge } 5 \\
\text { Methods to } \\
\text { improve } \\
\text { teamwork } 3\end{array}$ & $\begin{array}{l}\text { Knowledge } 6 \\
\text { Methods to } \\
\text { improve } \\
\text { teamwork } 4\end{array}$ & $\begin{array}{l}\text { Knowledge } 7 \\
\text { Developmental } \\
\text { process of } \\
\text { a team }\end{array}$ & \\
\hline \multirow[b]{2}{*}{$3 \mathrm{~min}$} & \multirow{3}{*}{$\begin{array}{l}\text { Orientation } \\
\text { Understand } \\
\text { the learning } \\
\text { objective } \\
\text { and learning } \\
\text { plan } \\
\text { Divide into } \\
\text { teams }\end{array}$} & \multicolumn{6}{|c|}{ Confirmation of team tasks } & \multirow{4}{*}{ Presentation } \\
\hline & & \multicolumn{3}{|c|}{$\begin{array}{l}\text { Improve the level of performance of the } \\
\text { tricks they can make. Increase the number } \\
\text { of tricks of high level of performance. }\end{array}$} & \multicolumn{2}{|c|}{$\begin{array}{l}\text { Increase the number of } \\
\text { tricks that all team mem- } \\
\text { bers can make. The tricks } \\
\text { already mastered should be } \\
\text { improved for better perfor- } \\
\text { mance. }\end{array}$} & $\begin{array}{l}\text { Practice } \\
\text { towards the } \\
\text { presentation }\end{array}$ & \\
\hline $20 \mathrm{~min}$ & & \multicolumn{3}{|c|}{$\begin{array}{l}\text { + Improve the skills they have. } \\
\text {-Understand the point of the techniques } \\
\text { and improve the level of performance. } \\
\text { - Teach each other and practice while } \\
\text { evaluating each other's skills. } \\
\text { Jump techniques; Basic tricks (straddle } \\
\text { jump) } \\
\text { Turn techniques; Basic tricks (forward roll } \\
\text { on vault, head spring) }\end{array}$} & \multicolumn{2}{|c|}{$\begin{array}{l}+ \text { Challenge difficult tricks } \\
\text { and increase the tricks they } \\
\text { can perform. } \\
\text { - Teach each other among } \\
\text { the team members during } \\
\text { practice. }\end{array}$} & \multirow{2}{*}{$\begin{array}{l}\text { Practice for } \\
\text { the presenta- } \\
\text { tion }\end{array}$} & \\
\hline $17 \mathrm{~min}$ & $\begin{array}{l}\text { member can } \\
\text { perform }\end{array}$ & \multicolumn{3}{|c|}{$\begin{array}{l}\text { + Challenge difficult tricks } \\
\text { - Teach each other and practice while } \\
\text { evaluating each other's skills. } \\
\text { Jump techniques; advanced tricks (stretch- } \\
\text { ed straddle jump, tuck jump) } \\
\text { Turn techniques; advanced tricks (bent } \\
\text { arms front handspring, front handspring) }\end{array}$} & \multicolumn{2}{|c|}{$\begin{array}{l}\text { + Improve the level of per- } \\
\text { formance of difficult tricks }\end{array}$} & & \\
\hline \multirow{2}{*}{$5 \mathrm{~min}$} & \multicolumn{7}{|c|}{ Team and individual reflections, summary of this period, and confirmation of notable points for the next period } & Reviews on the \\
\hline & $\begin{array}{c}\text { Review } \\
\text { Knowledge } 1\end{array}$ & $\begin{array}{c}\text { Review } \\
\text { Knowledge } 2\end{array}$ & $\begin{array}{c}\text { Review } \\
\text { Knowledge } 3\end{array}$ & $\begin{array}{c}\text { Review } \\
\text { Knowledge } 4\end{array}$ & $\begin{array}{c}\text { Review } \\
\text { Knowledge } 5\end{array}$ & $\begin{array}{c}\text { Review } \\
\text { Knowledge } 6\end{array}$ & $\begin{array}{c}\text { Review } \\
\text { Knowledge } 7\end{array}$ & $\begin{array}{l}\text { mental process, } \\
\text { unit summary }\end{array}$ \\
\hline
\end{tabular}

\subsection{Investigated items}

\subsubsection{Formative evaluation of friendship-building}

The ASKS model is an instructional model that was developed to facilitate interaction with others. It is considered that if the model functions effectively, students' collective and cooperative interaction activity in PE classes will become more active. Therefore, in order to evaluate students' collective and cooperative interaction activity in PE classes, we used a formative evaluation of friendshipbuilding created by Komatsuzaki et al. (2001).

A formative evaluation of friendship-building is a self-report scale where you answer to 10 questions on a collective and cooperative interaction activity in PE classes using three options of "Yes", "Neither yes nor no", and "No". Similar to
Umegaki et al. (2016b, p.11), we considered that we could measure the students' awareness of the collective and cooperative interaction activity that they had acquired up to that time by setting learning situations that would facilitate interaction with others in a target class and decided to conduct it before and after the unit. Additionally, Komatsuzaki et al. (2001, p.64) examined the reliability of the formative evaluation of friendship-building using 10 questions. Therefore, our study focused on and analyzed the average scores of the 10 answers.

\subsubsection{Scale of social skills}

We used Kikuchi's Scale of Social Skills: 18 items (hereinafter abbreviated as "KiSS-18") created by Kikuchi (1988). KiSS-18 is a scale to measure the degree of social skills a person has acquired 
Table 6 Unit plan for basketball.

\begin{tabular}{|c|c|c|c|c|c|c|c|c|}
\hline & $1^{\text {st }}$ period & $2^{\text {nd }}$ period & $3^{\text {rd }}$ period & $4^{\text {th }}$ period & $5^{\text {th }}$ period & $6^{\text {th }}$ period & $7^{\text {th }}$ period & $8^{\text {th }}$ period \\
\hline \multirow[b]{2}{*}{$5 \mathrm{~min}$} & \multicolumn{7}{|c|}{ Warm-up, greeting } & \multirow[b]{2}{*}{$\begin{array}{l}\text { Warm-up } \\
\text { Greeting } \\
\text { Confirmation } \\
\text { of tasks }\end{array}$} \\
\hline & $\begin{array}{l}\text { Knowledge } 1 \\
\text { What a } \\
\text { team is }\end{array}$ & $\begin{array}{l}\text { Knowledge } 2 \\
\text { What } \\
\text { teamwork is }\end{array}$ & $\begin{array}{l}\text { Knowledge } 3 \\
\text { Methods to } \\
\text { improve } \\
\text { teamwork } 1\end{array}$ & $\begin{array}{l}\text { Knowledge } 4 \\
\text { Methods to } \\
\text { improve } \\
\text { teamwork } 2\end{array}$ & $\begin{array}{c}\text { Knowledge } 5 \\
\text { Methods to } \\
\text { improve } \\
\text { teamwork } 3\end{array}$ & $\begin{array}{l}\text { Knowledge } 6 \\
\text { Methods to } \\
\text { improve } \\
\text { teamwork } 4\end{array}$ & $\begin{array}{l}\text { Knowledge } 7 \\
\text { Developmental } \\
\text { process of } \\
\text { a team }\end{array}$ & \\
\hline \multirow{3}{*}{$3 \mathrm{~min}$} & \multirow{3}{*}{$\begin{array}{l}\text { Orientation } \\
\text { Understand } \\
\text { the learning } \\
\text { objective } \\
\text { and learning } \\
\text { plan }\end{array}$} & \multicolumn{6}{|c|}{ Confirmation of tasks } & \multirow{5}{*}{$\begin{array}{l}\text { League match } \\
\text { between teams }\end{array}$} \\
\hline & & $\begin{array}{l}\text { Make stable sl } \\
\text { shots in coope } \\
\text { the team mem }\end{array}$ & $\begin{array}{l}\text { hots, create } \\
\text { rration with } \\
\text { bers }\end{array}$ & $\begin{array}{l}\text { Work togethe } \\
\text { teammates in } \\
\text { ate a space wi } \\
\text { ponents for } m \\
\text { Defend by ma } \\
\text { ponents. }\end{array}$ & $\begin{array}{l}\text { with the } \\
\text { order to cre- } \\
\text { thout the op- } \\
\text { laking a shot. } \\
\text { Irking the op- }\end{array}$ & $\begin{array}{l}\text { Make a shot } 1 \\
\text { nation play. } \mathrm{C} \\
\text { defense. }\end{array}$ & $\begin{array}{l}\text { using combi- } \\
\text { a zone }\end{array}$ & \\
\hline & & \multicolumn{6}{|c|}{ Check the tasks of the team, build the strategy } & \\
\hline $20 \mathrm{~min}$ & \multirow{2}{*}{$\begin{array}{l}\text { Divide into } \\
\text { teams } \\
\text { Trial game }\end{array}$} & \multicolumn{2}{|c|}{$\begin{array}{l}\text { Layup } \\
\text { Shooting off the dribble } \\
2 \text { on } 0,2 \text { on } 1\end{array}$} & \multicolumn{2}{|c|}{$\begin{array}{l}\text { Layup } \\
\text { Shooting off the dribble } \\
2 \text { on } 1,2 \text { on } 2\end{array}$} & \multicolumn{2}{|c|}{3 on 3 half-court } & \\
\hline $17 \mathrm{~min}$ & & \multicolumn{2}{|c|}{$\begin{array}{l}\text { Simple game } \\
3 \text { on } 2 \text { half-court } \\
\text { (without dribble) }\end{array}$} & $\begin{array}{l}\text { Simple game } \\
3 \text { on } 2 \text { half-co }\end{array}$ & & \multicolumn{2}{|c|}{5 on 5 full-court } & \\
\hline \multirow{2}{*}{$5 \mathrm{~min}$} & \multicolumn{7}{|c|}{ Team and individual reflections, summary of this period, and confirmation of notable points for the next period } & Reviews on the \\
\hline & $\begin{array}{c}\text { Review } \\
\text { Knowledge } 1\end{array}$ & $\begin{array}{c}\text { Review } \\
\text { Knowledge } 2\end{array}$ & $\begin{array}{c}\text { Review } \\
\text { Knowledge } 3\end{array}$ & $\begin{array}{c}\text { Review } \\
\text { Knowledge } 4\end{array}$ & $\begin{array}{c}\text { Review } \\
\text { Knowledge } 5\end{array}$ & $\begin{array}{c}\text { Review } \\
\text { Knowledge } 6\end{array}$ & $\begin{array}{c}\text { Review } \\
\text { Knowledge } 7\end{array}$ & $\begin{array}{l}\text { mental process, } \\
\text { unit summary }\end{array}$ \\
\hline
\end{tabular}

(Kikuchi, 1988, p.198). KiSS-18 is a self-report scale where you answer 18 questions on social skills using five options from "Always yes" to "Always no". Basically, we focused only on total scores targeting junior high schoolers and older (Kikuchi 2004, p.41).

\subsection{Ethical niceties}

This study was conducted after giving sufficient explanations about the study project and research details to the principal and relevant teacher of the cooperating school both in writing and orally and having obtained agreement. The research was conducted by the teacher during PE classes. Upon this, we asked the teacher to tell students the purposes of the research, that this research would not affect their academic grade, that they did not have to provide answers if they did not want to participate, and that they would not suffer any disadvantages if they did not provide answers. Incidentally, this study was conducted with approval from Ristumeikan University's Research Ethics Committee.

\subsection{Statistical processing}

For analysis, we used the IBM SPSS 22.0 for Windows. We set the significance level at $5 \%$. The target of the analysis was 30 students, who attended all the classes and provided all the research data without any omissions.

\section{Results}

\subsection{Results of the formative evaluation of frien- dship-building}

Table 7 shows the mean scores, standard deviation, one-way analysis of variance, and multiple comparison of the formative evaluation of friendship-building.

We examined the impact of the difference in team organization on the average scores of formative evaluation. We therefore conducted corresponding one-way analysis of variance with measuring timing as an independent variable and the average scores of the formative evaluation of friendship-building as a dependent variable. As a result, the major effect of 
Table 7 Mean scores, standard deviation, one-way analysis of variance, and multiple comparison of the formative evaluation of friendship-building.

\begin{tabular}{|c|c|c|c|c|c|c|c|c|c|c|c|}
\hline \multirow{3}{*}{\multicolumn{2}{|c|}{$\begin{array}{c}\text { Non-intervention } \\
\text { (1) } \\
\text { Pre } \\
\text { Short-distance } \\
\text { race and relay }\end{array}$}} & \multicolumn{4}{|c|}{ ASKS model (homogeneous team) } & \multicolumn{4}{|c|}{ ASKS model (heterogeneous team) } & \multirow{4}{*}{$F$} & \multirow{4}{*}{$\begin{array}{l}\text { Multiple } \\
\text { comparison } \\
\text { Bonferroni } \\
(p<.05)\end{array}$} \\
\hline & & \multirow{2}{*}{\multicolumn{2}{|c|}{$\begin{array}{c}(2) \\
\text { Pre } \\
\text { Exercise using } \\
\text { vaulting boxes }\end{array}$}} & \multirow{2}{*}{\multicolumn{2}{|c|}{$\begin{array}{c}\text { (3) } \\
\text { Post } \\
\text { Exercise using } \\
\text { vaulting boxes }\end{array}$}} & \multirow{2}{*}{\multicolumn{2}{|c|}{$\begin{array}{c}(4) \\
\text { Pre } \\
\text { Basketball }\end{array}$}} & \multirow{2}{*}{\multicolumn{2}{|c|}{$\begin{array}{l}\text { (5) } \\
\text { Post } \\
\text { asketball }\end{array}$}} & & \\
\hline & & & & & & & & & & & \\
\hline$M$ & $S D$ & $M$ & $S D$ & $M$ & $S D$ & $M$ & $S D$ & $M$ & $S D$ & & \\
\hline 2.43 & 0.33 & 2.51 & 0.35 & 2.56 & 0.33 & 2.49 & 0.41 & 2.69 & 0.31 & $6.63^{* * *}$ & $(1),(2),(4)<(5)$ \\
\hline
\end{tabular}

Table 8 Mean scores, standard deviation, one-way analysis of variance, and multiple comparison of KiSS-18.

\begin{tabular}{|c|c|c|c|c|c|c|c|c|c|c|c|}
\hline \multirow{3}{*}{\multicolumn{2}{|c|}{$\begin{array}{c}\text { Non-intervention } \\
(1) \\
\text { Pre } \\
\text { Short-distance } \\
\text { race and relay }\end{array}$}} & \multicolumn{4}{|c|}{ ASKS model (homogeneous team) } & \multicolumn{4}{|c|}{ ASKS model (heterogeneous team) } & \multirow{4}{*}{$F$} & \multirow{4}{*}{$\begin{array}{l}\text { Multiple } \\
\text { comparison } \\
\text { Bonferroni } \\
(p<.05)\end{array}$} \\
\hline & & \multirow{2}{*}{\multicolumn{2}{|c|}{$\begin{array}{c}(2) \\
\text { Pre } \\
\text { Exercise using } \\
\text { vaulting boxes }\end{array}$}} & \multirow{2}{*}{\multicolumn{2}{|c|}{$\begin{array}{l}\text { (3) } \\
\text { Post } \\
\text { Exercise using } \\
\text { vaulting boxes }\end{array}$}} & \multirow{2}{*}{\multicolumn{2}{|c|}{$\begin{array}{c}(4) \\
\text { Pre } \\
\text { Basketball }\end{array}$}} & \multirow{2}{*}{\multicolumn{2}{|c|}{$\begin{array}{l}\text { (5) } \\
\text { Post } \\
\text { 3asketball }\end{array}$}} & & \\
\hline & & & & & & & & & & & \\
\hline$M$ & $S D$ & $M$ & $S D$ & $M$ & $S D$ & $M$ & $S D$ & $M$ & $S D$ & & \\
\hline 60.10 & 9.04 & 62.33 & 9.05 & 63.73 & 10.19 & 62.57 & 9.00 & 66.03 & 9.67 & $6.90 * * *$ & $(1),(2),(4)<(5)$ \\
\hline
\end{tabular}

measuring timing was found to be significant $(F(4$, $116)=6.63, p<.001)$. As a result of multiple comparisons using Bonferroni, the average scores of the formative evaluation of friendship-building were significantly high after basketball (5) compared to before short-distance race and relay (1) (2.69> 2.43); after basketball (5) compared to before exercise using vaulting boxes (2) $(2.69>2.51)$; and after basketball (5) compared to before basketball (4) $(2.69>2.49)$. In short, more activeness in students' collective and cooperative interaction activity was witnessed in PE classes with the ASKS model with heterogeneous team organization.

\subsection{Results of KiSS-18 in the entire students}

Table 8 shows the mean scores, standard deviation, one-way analysis of variance, and multiple comparison of KiSS-18.

In order to examine the impact of the difference in team organization on the average scores of KiSS18 , we conducted corresponding one-way analysis of variance, with measuring timing as an independent variable and the average scores of KiSS-18 as a dependent variable. As a result of adjusting the degree of freedom by the Greenhouse-Geisser correction due to violations of the sphericity assumption, the major effect of measuring timing was found to be significant $(F(2.91,84.35)=6.90, p$ $<.001)$. As a result of multiple comparison using Bonferroni, the average scores of KiSS- 18 were significantly high after basketball (5) compared to before short-distance race and relay (1) (66.03> 60.10); after basketball (5) compared to before exercise using vaulting boxes (2) $(66.03>62.33)$; and after basketball (5) compared to before basketball (4) $(66.03>62.57)$. In short, improvement in the entire students' social skills was witnessed in PE classes with the ASKS model with heterogeneous team organization.

\subsection{Results of KiSS-18 in each group}

In order to examine the impact of the difference in team organization on the high-score/low-score groups of KiSS-18, we divided the entire class into two groups based on the average scores of KiSS-18 before short-distance race and relay. Based on the frequency distribution of the entire class, those higher than the central value were set as the highscore group of KiSS-18, and those lower as the lowscore group. Table 9 shows the mean scores, standard deviation, two-way analysis of variance, and multiple comparisons of the high-score/low-score groups of KiSS-18.

In order to examine whether or not the average 
Table 9 Mean scores, standard deviation, two-way analysis of variance, and multiple comparison of the high-score/low-score groups of KiSS-18.

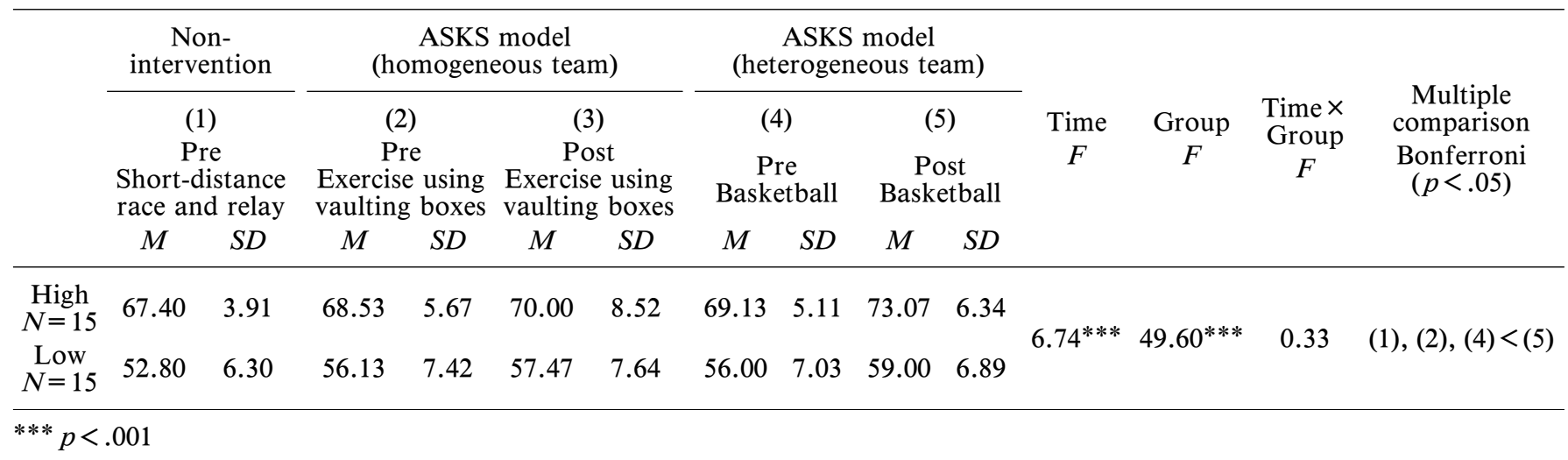

scores of KiSS-18 would differ depending on the team organization and the group level (high score/low score) of KiSS-18, we conducted a twoway analysis of variance with measuring timing (5) and the group level of KiSS-18 (2) as an independent variable and the average scores of KiSS-18 as a dependent variable. As a result of adjusting the degree of freedom by the Greenhouse-Geisser correction due to the violations of the sphericity assumption, the major effect of measuring timing was found to be significant $(F(2.89,80.83)=6.74, p$ $<.001)$ and the major effect of the group level of KiSS-18 was found to be significant $(F(1,28)=$ $49.60, p<.001)$ but the interaction effect was not $(F$ $(2.89,80.83)=0.33$, n.s. $)$. Next, we conducted multiple comparisons using Bonferroni. As a result, the average scores of KiSS-18 were significantly high "after basketball (5) compared to before shortdistance race and relay (1)", "after basketball (5) compared to before exercise using vaulting boxes (2)", and "after basketball (5) compared to before basketball (4)"'. In short, improvement of the students' social skills was witnessed in PE classes with the ASKS model with heterogeneous team organization both for the high-score and the low-score groups of KiSS-18.

\subsection{Results of KiSS-18 in each team of the heter- ogeneous intervention unit}

Table 10 shows the mean scores, standard deviation, and $t$-test of KiSS- 18 for each team of the heterogeneous intervention unit.

In order to examine whether or not the average scores of KiSS-18 in the heterogeneous intervention unit would differ before and after the application of
Table 10 Mean scores, standard deviation, and $t$-test of KiSS18 for each team of the heterogeneous intervention unit.

\begin{tabular}{|c|c|c|c|c|c|c|}
\hline & \multirow[t]{2}{*}{$N^{\dagger}$} & \multicolumn{2}{|c|}{$\begin{array}{c}\text { Pre } \\
\text { Basketball }\end{array}$} & \multicolumn{2}{|c|}{$\begin{array}{c}\text { Post } \\
\text { Basketball }\end{array}$} & \multirow[t]{2}{*}{$t$} \\
\hline & & $M$ & $S D$ & $M$ & $S D$ & \\
\hline A & 6 & 69.33 & 4.72 & 74.83 & 6.08 & $-4.79 * *$ \\
\hline B & 9 & 61.78 & 8.00 & 65.11 & 9.39 & $-2.41^{*}$ \\
\hline $\mathrm{C}$ & 7 & 60.29 & 11.40 & 63.86 & 11.31 & $-2.53^{*}$ \\
\hline D & 8 & 60.38 & 9.21 & 62.38 & 7.95 & -1.03 n.s. \\
\hline
\end{tabular}

${ }^{\dagger}$ It shows the number of students who attended all classes and students who completed the survey data.

the ASKS model with heterogeneous team organization, we conducted a corresponding $t$-test. As a result, three teams showed significantly-higher average scores of KiSS-18 after the unit compared to before the unit $(\mathrm{A} ; t(5)=-4.79, p<.01, \mathrm{~B} ; t(8)$ $=-2.41, p<.05, \mathrm{C} ; t(6)=-2.53, p<.05)$. Team D showed no significant difference in the average scores of Kiss-18 before and after the unit.

\section{Discussion}

The purpose of this study was to examine the style of team organization with which the effectiveness of the ASKS model can be witnessed by comparing PE classes with the ASKS model with homogeneous team organization and those with heterogeneous team organization.

As a result, as a case example, this study showed the following matters. That is, the ASKS model with heterogeneous team organization compared to the ASKS model with homogeneous team organization first increased the students' awareness of collective and cooperative interaction activity in $\mathrm{PE}$ 
classes, and second, facilitated the improvement of the social skills all students, as well as the high-score and low-score groups of KiSS-18. Thus, it was indicated that the effectiveness of the ASKS model can be witnessed not with homogeneous team organization but with heterogeneous team organization. One of the factors for this result could be the following.

That is, students in a heterogeneous team possibly had more opportunities to use the knowledge that they learned in the intervention unit compared to students in a homogeneous team.

The knowledge provided to students in intervention-unit classes was about team building. Specifically, students were taught to structurally understand the knowledge necessary for ideal team building such as "what a team is", "what teamwork is", "methods to improve teamwork", and the "developmental process of a team" while interrelating them. Among them, knowledge related to the methods to improve teamwork, especially, can facilitate the improvement of social skills on how to communicate with team members, how to take leadership, and understanding the situation of members and supporting them.

For example, students became able to find members who was not good at the subject, and learned as knowledge to give advice suited to their personality and skill level. Because students were aware that their collective and cooperative interaction activity became more active in PE classes with the ASKS model with heterogeneous team organization than those with homogeneous team organization, the following matters can be surmised. That is, collective and cooperative interaction activity possibly was not active on teams whose members were homogeneous in skills because the difference in their skill level among members was small, and there were fewer things to advise each other. Meanwhile it is surmised that, when members' skills were heterogeneous, they gave a wide variety of advice, and collective and cooperative interaction activity became active.

From the above, it is assumed that students in heterogeneous teams had more opportunities to use the knowledge that they newly learned through intervention units than those in homogeneous teams and were able to understand the knowledge more deeply, and as a result that the improvement of their social skills for smoother interpersonal relations was witnessed.
Next, we will discuss the characteristics of members with which the effectiveness of the ASKS model can be witnessed.

When looking at the impact of heterogeneous intervention unit on KiSS-18 for each team, the improvement of students' social skills was witnessed on three teams but not on one team.

Table 11 shows the characteristics of each team of the heterogeneous intervention unit. The characteristics of KiSS-18 of each team were as follows: Team A contained five high-average-score members of KiSS-18 and one low-average-score member of KiSS-18; Team B contained five high-average-score members of KiSS-18 and four low-average-score member of KiSS-18; Team C contained two highaverage-score members of KiSS-18 and five lowaverage-score members of KiSS-18; and Team D contained three high-average-score members of KiSS-18 and five low-average-score members of KiSS-18. Meanwhile, the characteristics of motor skill ${ }^{* 7}$ of each team were as follows: Team A contained three high-level members, one mid-level member, and two low-level members; Team B contained three high-level members, four mid-level members, and two low-level members; Team $\mathrm{C}$ contained four high-level members, one mid-level member, and two low-level members; and Team D contained one high-level member, five mid-level members, and two low-level members.

Looking at Table 11, we can consider that the factor that affected the improvement of social skills was not that the characteristics of KiSS-18 were heterogeneous but possibly that the characteristics of motor skill were heterogeneous. This is because, when comparing Teams $\mathrm{A}, \mathrm{B}$ and $\mathrm{C}$ in which the improvement of social skills was witnessed and Team D in which it was not, Team D was less heter-

Table 11 Characteristics of each team of the heterogeneous intervention unit.

\begin{tabular}{|c|c|c|c|c|c|c|}
\hline & & \multicolumn{2}{|c|}{$\begin{array}{c}\text { Characteristic of } \\
\text { KiSS-18 } \\
\text { Team }\end{array}$} & $\begin{array}{c}\text { Number } \\
\text { of } \\
\text { members }\end{array}$ & \multicolumn{2}{|c|}{$\begin{array}{c}\text { Characteristic of } \\
\text { motor skill } \\
\text { (number of members) }\end{array}$} \\
\cline { 3 - 7 } & $\begin{array}{c}\text { Members } \\
\text { nith high } \\
\text { scores }\end{array}$ & $\begin{array}{c}\text { Members } \\
\text { with low } \\
\text { scores }\end{array}$ & High & $\begin{array}{c}\text { Middle- } \\
\text { grade }\end{array}$ & Low \\
\hline A & 6 & 5 & 1 & 3 & 1 & 2 \\
B & 9 & 5 & 4 & 3 & 4 & 2 \\
C & 7 & 2 & 5 & 4 & 1 & 2 \\
D & 8 & 3 & 5 & 1 & 5 & 2 \\
\hline
\end{tabular}


ogeneous in terms of characteristics of motor skill than the other teams.

In the heterogeneous intervention unit, upon organizing heterogeneous teams, we assigned to each team three to four students belonging to the basketball club and one to two students having leadership. However, Team D, from the viewpoint of motor skill, contained only one student at a high-level and was mostly composed of mid-level and low-level students. In the stage of junior high school, it seems that belonging to the basketball club does not necessarily correspond with the level of motor skill basketball performance. In the basketball unit, the teacher tried to secure heterogeneity within each team by dispersing students belonging to the basketball club to different teams, but as it turned out, Team D was mainly composed of students whose motor skill was in a mid or low level. Team D seemed not to be heterogeneous enough in terms of motor skill. Namely, it is considered that the effectiveness of the ASKS model is produced when heterogeneity in motor skill is witnessed in the members. The factor that brought such a result can be as follows.

That is, in the ASKS model, students possibly conducted interactions through motor skill.

The ASKS model aims at team building for sports teams. The four teams in the basketball unit addressed their team building aiming at winning interteam games or enjoying playing as a team. In the ASKS model, in order to increase teamwork, we let students understand that they would solve tasks related to motor skill such as "all the members to acquire the skills of basketball" and "planning a strategy that all the members can play actively," and solve tasks related to human relations within a team such as "easing the atmosphere of the team," and guided them to implement such acts. In order to increase teamwork, you need to solve issues related to task solution and issues related to human relations in a well-balanced way (Yamaguchi, 2008). In the ASKS model, we encouraged consideration to human relations within a team through advising in a tone of voice suited to the personality of the members and giving advice that would motivate the members. Such advice taking human relations into consideration was conducted via the members' motor skill. Specifically, students gave advice related to technical tips for getting better or how to move during a game in a soft and encouraging tone or in a lit- tle strong tone for firing up. In this sense, we assume that interaction between students becomes more active by securing heterogeneity in motor skill.

From the above, it was indicated that the effectiveness of the ASKS model could be witnessed when not the heterogeneity of the members' social skills but the heterogeneity of their motor skill is secured. These results seem to be supporting the aforementioned finding that the effectiveness of the ASKS model can be witnessed with heterogeneous team organization.

\section{Summary}

The purpose of this study was to examine the style of team organization with which the effectiveness of the ASKS model can be witnessed by comparing PE classes with the ASKS model with homogeneous team organization and those with heterogeneous team organization.

As a result as a case example, the following two points were clarified: the effectiveness of the ASKS model could be witnessed firstly with heterogeneous team organization, and secondly by securing not the heterogeneity of social skills but the heterogeneity of motor skill.

However, the following tasks are left in this study.

The first task is to analyze conversations between members within a homogeneous team and within a heterogeneous team in PE classes with the ASKS model. This study examined the style of team organization with which the effectiveness of the ASKS model can be witnessed by conducting questionnaire surveys of a formative evaluation of friendshipbuilding and KiSS-18. However, by analyzing conversations between members within each team, we may be able to reveal the way of interaction between members within a team that facilitates the improvement of social skills.

The second task is to examine the number of team members with which the effectiveness of the ASKS model can be produced. In this study, the number of team members was five to six in the exercise using vaulting boxes unit, and seven to nine in the basketball unit. By examining the number of team members that produces the effectiveness of the ASKS model and facilitates the improvement of their social skills, we may be able to provide find- 
ings more effective for PE classes.

The third task is to examine the effectiveness of the ASKS model in gender-mixed PE classes. This study targeted at PE classes for male junior highschool students. If the effectiveness of the ASKS model is witnessed with heterogeneous team organization, we may need to examine its effectiveness under sexual heterogeneity.

\section{Acknowledgments}

This study was realized thanks to the cooperation by the principal, teachers, and faculty members and students of a municipal junior high school of City $\mathrm{K}$. We would like to take this opportunity to thank them.

\section{Notes}

1. “協調的問題解決 (Kyochotekimondaikaiketsu)" is translated into English as "collaborative problem solving". A similar expression is "collaborative learning". "Collaborative" is translated as “協調 (Kyocho)" (Miyake et al., 2002; Shirozu et al., 2014) or “協働 (Kyodo)” (Akita, 2008). In this study, it is described as “協働 (Kyodo)" in accordance with the Course of study, except when using the original description when quoting from other materials.

2. Sugiyama et al. $(2010$, p.84) tried to create a scale that can be used for examining the generalization of psychosocial skills in PE classes into life skills and demonstrated the relevance of considering that psychosocial skills in $\mathrm{PE}$ classes and life skills are interrelated but not the same. Life skills refer to social skills in daily life settings. Additionally, Sasaki (2004) maintained the division between social skills in PE classes and social skills in daily life settings. This study also distinguishes between social skills that students have acquired in PE classes and social skills in daily life settings.

3. A heterogeneous team refers to a group consisting of people with large difference in ability, personalities, or knowledge. Meanwhile, a group consisting of people with little differences in ability, personalities, or knowledge is called a homogeneous team.

4. Character formation in PE is defined as an "activity facilitating students to acquire sociality and morality during they are learners"' (Tomozoe, 2009, p.54).

5. Sato and Nagai (2000) focusing on ball games for uppergrade elementary school students, examined the effect of PE classes with homogeneous groups set to some parts of the learning process. Specifically, they conducted heterogeneous group learning (five classes) homogenous group learning (five classes) and heterogeneous group learning (three classes) within one unit, as well as heterogeneous group learning (13 classes) throughout a unit and compared their effects. As a result, they revealed that, by setting homogeneous group learning, they were able to increase children's motivation toward sports and make their movement active.

6. Ichikawa $(2000, p .363)$ pointed out that they were able to deepen students' understanding by linguistically describing the concept, significance and procedures of what they were to learn. In our study, in order to deepen students' understanding during the classes, we guided them to note down the knowledge that they learned during the classes in words of their own.
7. We asked the teacher to, before conducting the intervention unit, divide students into three grades of high level, midlevel and low level in general motor skill based on the results of the New Physical Fitness Test. The result was almost the same as the result of the three grades that divided students based on exercise using vaulting boxes skill in the homogeneous intervention unit, only except four students.

\section{References}

Akita, K. (2008). kodomo o hagukumu jugyozukuri: Chi no sozo he [Creation of classes that cultivate children: Towards the creation of knowledge]. Tokyo: Iwanami Shoten. (in Japanese)

Anderson, L. W., Krathwohl, D. R., Airasian, P. W., Cruikshank, K. A., Mayer, R. E., Pintrich, P. R., Raths, J., and Wittrock, M. C. (eds.) (2001). A taxonomy for learning, teaching, and assessing: A revision of Bloom's taxonomy of educational objectives (Abridged Edition). New York: Longman.

Central Council for Education (2016). Yochien, shogakko, chugakko, kotogakko oyobi tokubetsushiengakko no gakushushidoyoryo nado no kaizen oyobi hitsuyona hosaku nado nitsuite [Improvement of the Courses of Study for kindergarten, elementary school, junior high school, high school, and special support school and other necessary measures].

http://www.mext.go.jp/b_menu/shingi/chukyo/chukyo0/ toushin/ _ _ icsFiles/afieldfile/2017/01/10/1380902 _ 0.pdf, (accessed 2017-08-31).

Curriculum Planning Special Committee (2015). 2030nen ni muketa kyoiku no arikata ni kansuru dainikai Nihon· OECD seisaku taiwa (hokoku) kyoiku katei bukai kyoiku katei kikaku tokubetsubukai (12kai) haifu shiryo [The second Japan-OECD Policy Dialogue on Education Towards 2030 (report), a handout (12 $2^{\text {th }}$ edition) by the School Curriculum Committee, Special committee for Curriculum Planning]. (in Japanese)

http://www.mext.go.jp/b menu/shingi/chukyo/chukyo3/ 053/siryo/__icsFiles/afieldfile/2015/08/04/1360597_6_1. pdf, (accessed 2017-08-31).

Dyson, B. (2001). Cooperative learning in an elementary physical education program. J. Teach. Phys. Educ., 20(3): 264-281.

Dyson, B. (2002). The implementation of cooperative learning in an elementary physical education program. J. Teach. Phys. Educ., 22(1): 69-85.

Gordon, B. and Doyle, S. (2015). Teaching personal and social responsibility and transfer of learning: Opportunities and challenges for teachers and coaches. J. Teach. Phys. Educ., 34(1):152-161.

Griffin, P., McGaw, B., and Care, E. (2014). 21世紀型スキル: 学びと評価の新たなかたち (N. Miyake Trans.). Kyoto: Kitaoji Shobo. (Original work "Assessment and teaching of $21^{\text {st }}$ century skills" published 2012)

Hellison, D. (2003). Teaching responsibility through physical activity, second edition. Champaign, IL: Human Kinetics.

Hellison, D. and Walsh, D. (2002). Responsibility-based youth programs evaluation: Investigating the investigations. Quest, 54: 292-307.

Hida, M. (2014a). Group problem solving performance by members of homogeneous and heterogeneous groups on the unfamiliar intellective task. Bull. Fac. Hum. Dev. Cult. Fukushima Univ., 19: 41-52. (in Japanese) 
Hida, M. (2014b). Group problem solving performance by members of homogeneous and heterogeneous groups: effects of task difficulty. Bull. Fac. Hum. Dev. Cult. Fukushima Univ., 20: 29-36. (in Japanese)

Hida, M. (2014c). Group problem solving performance by members of homogeneous and heterogeneous groups. JJESP, 54(1): 55-67. (in Japanese)

Ichikawa, S. (2000). Promoting verbal descriptions of concepts, diagrams, and procedures in learning: Suggestions and discussion through cases of cognitive counseling. Jpn. J. Educ. Psychol., 48(3): 361-371. (in Japanese)

Ishii, T. (2011). Development of theories on educational objectives and assessment in the United States: Designing standards-based curriculum. Tokyo: Toshindo. (in Japanese)

Izuhara, Y. (1986). Taiiku no gakushu shudanron [Learning group theory in Physical Education]. Tokyo: Meiji-Tosho. (in Japanese)

Izuhara, Y. (1991). "Minnaga umakunarukoto o" oshieru taiiku [Physical Education that teaches "everyone to improve their skills"']. Tokyo: Taishukan-Shoten. (in Japanese)

Izuhara, Y. (2004). Ishitsu kyodo no manabi [Learning in cooperation between heterogeneous individuality]. Tokyo: Sobun-Kikaku. (in Japanese)

Kikuchi, A. (1988). Omoiyari o kagaku suru [Science of compassion]. Tokyo: Kawashima-Shoten. (in Japanese)

Kikuchi, A. (2004). Notes on the researches using KiSS-18. Bull. Fac. Soc. Welf. Iwate Prefectural Univ., 6(2): 4-51. (in Japanese)

Kinjo, H. (2015). The merit of heterogeneous group in problem solving situation: Focusing on graphic score making in music appreciation class. Ryukyu daigaku kyuikugakubu ongakuka ronshu., 4: 79-93. (in Japanese)

Komatsuzaki, S., Yonemura, K., Miyake, K., Hasegawa, E., and Takahashi, T. (2001). Developing a formative evaluation instrument forcusing on students' interactive and cooperative behaviors in physical education class. JJSES, 21(2): 57-68. (in Japanese)

Kuno, H. (2015). Kokusai gakuryoku chosaga tou "gakuryoku" toha nanika? [What is the academic ability that is assessed by the Programme for International Student Assessment (PISA)]. In Nasu, M., Kuno, H., and Saito, K. (ed.), Chishiki kiban shakai o ikinuku kodomo o sodateru [Educate children who survive a knowledge-based society]. Tokyo: Gyosei. (in Japanese)

Miyake, N., Miyake, Y., and Shirozu, H. (2002). Cognitive Science and the learning sciences. Cognitive Studies, 9(3): 328-337. (in Japanese)

MEXT (2017). Course of study for junior high schools. (in Japanese)

http://www.mext.go.jp/component/a _ menu/education/ micro _ detail/ _ _ icsFiles/afieldfile/2017/06/21/1384661 _ 5.pdf, (accessed 2017-08-31).

Okade, Y. (2017). Kotonaru bummyaku kara shin gakushushido yoryo o mitsumeru [Analyze the new Courses of Study from different perspectives]. Taiikukakyoiku, 65(7): 9. (in Japanese)

Richen, D. S. and Salganik, L. H. (2003). Key competencies for a successful life and a well-functioning society. Cambridge: Hogrefe \& Huber.

Sasaki, B. (2004). Analysis of junior high school students' social skills in physical education classes: with a special reference to their genders, grades, and adjustments to physical education classes. Jpn. J. Phys. Educ. Health. Sport. Sci.,
49(5): 423-434. (in Japanese)

Sato, K. and Nagai, T. (2000). The learning process of ball games which all children are satisfied with: The verification of effect on learning by the same quality group. Kyoiku jissen kenkyu shido senta kenkyu kiyo, 19: 119-130. (in Japanese)

Shirozu, H., Miyake, N., and Masukawa, H. (2014). New developments of the learning sciences: Turning sciences of learning into practice. Cognitive Studies, 21(2): 254-267. (in Japanese)

Siedentop, D. (1994). Sport education: Quality PE through positive sport experiences.Champaign, IL: Human Kinetics. (in Japanese)

Sugiyama, Y., Shibukura, T., Nishida, T., Ito, T., Sasaki, B., and Isogai, H. (2010). Development of scales for psychosocial skills in physical education and life skills. J. Health. Sci., 32: 77-84. (in Japanese)

Tomita, K. (2007). Management of differences and similarities in strategic alliances. Iryo to Shakai, 17(1): 113-123. (in Japanese)

Tomozoe, H. (2009). Character building in school physical education. Tokyo: Taishukan-Shoten. (in Japanese)

Tomozoe, H. (2010). Taiiku no mokuhyo to naiyo [Goals and contents of physical education]. Takahashi, T., Okade, Y., Tomozoe, H., and Iwata, Y.(eds.), Introduction to sport pedagogy. Tokyo: Taishukan-Shoten. (in Japanese), pp.30-38.

Umegaki, A., Tomozoe, H., and Osaka, M. (2006). A study on the effectiveness of the character education program in school physical education. Jpn. J. Pedagogy Phys. Educ., 22(2): 11-22. (in Japanese)

Umegaki, A., Kusajima, S., and Uetani, K. (2011). Empirical study on the effectiveness of the TPSR model in a junior high school class. Jpn. J. Phys. Educ. Health Sport Sci., 56(1): 157-172. (in Japanese)

Umegaki, A., Otomo, S., Minamishima, E., Ueta, K., Fukada, N., Yoshii, T., and Miyao, N. (2016a). Study of the transfer and maintenance of the effects of the TPSR model in junior high school physical education classes. Jpn J. Phys. Educ. Health Sport Sci., 61(2): 503-516. (in Japanese)

Umegaki, A., Otomo, S., Minamishima, E., Ueta, K., Fukada, N., Yoshii, T., and Miyao, N. (2016b). Development of team-building learning targeting physical education classes in junior high schools and examination of its effectiveness. Jpn. J. Pedagogy Phys. Educ., 32(2): 1-18. (in Japanese)

Umegaki, A., Otomo, S., Ueta, K., Fukada, N., Yoshii, T., and Miyao, N. (2017). Shakaiteki sukiru no kojo o unagasu taiiku niokeru shido moderu no kento: Chimuhensei no keitai ni chakumokushite [Examination of teaching models in physical education that promotes the improvement of social skills: Focusing on the structure of team formation]. JSPEHSS $68^{\text {th }}$ Convention, Oral presentation materials. (in Japanese)

Wallhead, T. and O'Sullivan, M. (2005). Sport education: Physical education for the new millennium? Phys. Educ. Sport Pedagogy., 10(2): 181-210.

Yamaguchi, H. (2008). Chimuwaku no shinrigaku yoriyoi shudan zukuri o mezashite [Psychology of teamwork: Aiming to create a better team]. Tokyo: Saiensu-Sha. (in Japanese)

Yamashita, S. (2002). Differences in communication on inertial force between a homogeneous group and a heterogeneous group. Jpn. J. Sci. Educ., 26(1): 3-11. (in Japanese) 
Name:

Akemi Umegaki

\section{Affiliation:}

School of Health and Sport Sciences, Osaka University of Health and Sport Sciences

Address:

1-1, Asashirodai, Kumatori, Sennan, Osaka, 590-0496, Japan Brief Biographical History:

2017 Received PH. D. at Ritsumeikan University

2011-Present Professor, School of Health and Sport Sciences, Osaka University of Health and Sport Sciences

2007-2011 Associate Professor, School of Health and Sport

Sciences, Osaka University of Health and Sport Sciences

2004-2007 Lecture, Hokkaido Asai Gakuen College, Hokkaido Asai Gakuen University

\section{Main Works:}

-Umegaki, A., Otomo, S., Minamishima, E., Ueta, K., Fukada, N., Yoshii, T., and Miyao, N. (2016). Development of Team-Building Learning Targeting Physical Education Classes in Junior High Schools and Examination of its Effectiveness. Japan Journal for the Pedagogy of Physical Education, 32(2): 1-18. (in Japanese)

-Umegaki, A., Otomo, S., Uetani, K., and Wayne, J. (2014). A Study of Fair Play in the Premodern Era: From the Perspective of N. Elias's Concept of Figuration. Japan Journal of Physical Education Health and Sport Sciences, 59(2): 513-527. (in Japanese)

Membership in Learned Societies:

-Japan Society of Physical Education, Health, and Sport Sciences

- Japan Society for the Philosophy of Sport and Physical Education

- Japan Society of Sport Education

- Japan Society for the Pedagogy of Physical Education

- The Japan Society of Sport History 